\title{
Considering the Ottoman Prayer Rugs in Light of New Collections
}

\author{
Mohamed Sahry Barshawy ${ }^{\mathrm{a}}$, Mohamed Ali Hamid Bayoumy Madkour ${ }^{\mathrm{b}}$, \\ ${ }^{a}$ PhD Researcher, Department of Tourist Guidance, Faculty of Tourism and \\ Hotels, Minia University. \\ b Professor of Archeology and Islamic Arts, Department of Tourist Guidance, \\ Faculty of Tourism and Hotels, Minia University
}

\section{Keywords}

Ottoman Prayer Rugs

\begin{abstract}
The Ottoman Turkish rugs preoccupy a prominent position among the Islamic rugs styles, which surpassed other prestigious styles not only in the Islamic world, but also throughout Europe .

The art of manufacturing Turkish rugs has kept pace with the Islamic history of Turkey, since the advent of Seljuks to Asia Minor in the 5th century AH / 11th AD( ). This art has reached its zenith position among the international art of rugs, and the Ottoman Turkey has shown the precedence in this field, which made it about to join Iran with its splendid fame in carpets. This position stemmed from the fact that the art of carpetmaking in general originated in the places where the Turks settled in the Central Asian region( ).
\end{abstract}




\section{Introduction}

The Ottoman Turkish rugs preoccupy a prominent position among the Islamic rugs styles, which surpassed other prestigious styles not only in the Islamic world, but also throughout Europe.

The art of manufacturing Turkish rugs has kept pace with the Islamic history of Turkey, since the advent of Seljuks to Asia Minor in the $5^{\text {th }}$ century $\mathrm{AH} / 11^{\text {th }} \mathrm{AD}^{(\mathrm{i})}$. This art has reached its zenith position among the international art of rugs, and the Ottoman Turkey has shown the precedence in this field, which made it about to join Iran with its splendid fame in carpets. This position stemmed from the fact that the art of carpet-making in general originated in the places where the Turks settled in the Central Asian region ${ }^{\text {(ii) }}$.

The Turks were able to develop this industry thanks to the availability of the huge potential of raw materials for weaving and dyeing as well as the way of knotting them on the one hand, and their influence with oriental carpets on the other. Remarkably, the $10^{\text {th }} \mathrm{AH}$ $/ 16^{\text {th }}$ century $\mathrm{AD}$ witnessed a brilliant artistic richness in the art of Turkish carpet-making, as it witnessed also a boom in the Ottoman Empire in terms of conquests and expansions, especially in Tabriz $620 \mathrm{AH} / 1514 \mathrm{AD}$, and Egypt $923 \mathrm{AH} / 1517$ AD. Hence, a new decorative technical concept was achieved in the Turkish carpet industry, which made the $11^{\text {th }} \mathrm{AH} / 17^{\text {th }}$ century $\mathrm{AD}$ so unique due to the multiplicity of its carpet styles that can be seen clearly in its decorative patterns.

\subsection{Considering this topic, the current study aims to the following:}

1- Shed light objectively on the nature and essence of Islamic arts in the Ottoman era.

2- Shed light on the art of Ottoman Turkish prayer rugs through new collections.

3- Shed light on the most important centers of producing prayer rugs in Ottoman Turkey and the most prominent features distinguishing them.

4- Learn about the ornamental designs executed on Ottoman prayer carpets, and study the artistic value of these ornaments, their elements and stages of development.

5- Highlight the most important industrial and decorative methods used by the Ottoman artist in the manufacture and ornamentation of these rare masterpieces, which adorn the international museums, and to clarify the aspects of the creativity of the Muslim artist. 
6- Identify the symbolism and doctrinal influences as depicted on the Ottoman prayer rugs.

\subsection{Importance of the Topic:}

1- It discusses an important type of Ottoman rugs, i.e., the prayer rugs.

2- It discusses methods of manufacturing rugs.

3- It deals with the types and production centers of Ottoman prayer rugs.

4- It deals with the decorations and colors used on these rugs.

\subsection{This topic was chosen for several reasons, including:}

1 - Realizing the types of Ottoman prayer rugs.

2- Knowing the artistic methods in manufacturing prayer rugs.

3 - Learning about the cities and regions of producing the Ottoman prayer rugs.

4- Learning about the vegetal and geometric patterns used in decorating the prayer rugs.

\subsection{Research Methodology:}

It relied on the descriptive analytical Approach; it is based on describing their nature, and analyzing the art of the artifacts.

The study addressed several questions as follows: What are the different types of Ottoman prayer rugs? Is there a difference between the types of Ottoman prayer rugs? What are the most important floral and geometric motifs on Ottoman prayer rugs from the eighth up to the twelfth century AH? What is the influence of floral and geometric motifs and their evolution on the prayer rugs? Have the Ottoman prayer rugs depicted any doctrinal influences?

\subsection{Ottoman Prayer Rugs:}

The industry of Ottoman prayer rugs aimed to designate a suitable and clean place for prayer, so the prayer rugs in particular attracted great attention and craftsmanship in their decoration and embellishment until they occupied a prominent position among all Islamic masterpieces ${ }^{(\mathrm{iii})}$.

The Turkish prayer rugs are matchless, and they proved the genius of Muslim artist who expressed his innate love for beauty and colors as well as his sincere religious sense, as he considered every knot in the rug as a means that increases his connection to Allah with His Majesty and Greatness. The prayer rug made the Muslim artist believe in a purely religious concept of reverence, obedience, and attachment to God. He managed to combine such influences together to produce this marvelous collection of prayer rugs ${ }^{(\mathrm{iv})}$. 


\subsection{Types of Turkish Prayer Rugs:}

\subsubsection{There are two types of Ottoman Prayer Rugs as follows: -}

1- Small Prayer Rugs: They are used for individual performance of Muslim prayers. This type is characterized by containing only one mihrab that is a semicircular niche indicating the qibla (facing the direction of Ka'ba when praying $)^{(\mathrm{v})}$.

2- Large Prayer Rugs: This type is characterized by depicting more than a mihrab indicating the direction of Qibla. This type can be used by several individuals ${ }^{\text {(vi) }}$.

\subsection{Centers of Turkish Prayer Rugs Production:}

They are all concentrated in the cities located between the Anatolian Mountains, where pastures are abundant and sheep wool is abundant as well. Most of these cities are located in the western region not far from the shore of the Mediterranean Sea ${ }^{\text {(vii) }}$. The most important of these cities are as follows:

\subsubsection{The city of Ushak:}

It is located in western Anatolia near the port of Izmir. It is considered one of the main areas of producing rugs in the Ottoman era $^{\text {(viii) }}$. The prayer rugs attributed to Ushaq are rare.

\section{The Most Important Features of Ushaq Prayer Rugs:}

- Small in size that tends to be square in shape.

- Tight texture, and large size of decorative elements. The pile decorations include a mihrab in the form of a three-lobed lobed $\operatorname{arch}^{(\mathrm{ix})}$.

- At the beginning of the $12^{\text {th }}$ century $\mathrm{AH} / 18^{\text {th }}$ century $\mathrm{AD}$, the artists of Ushaq showed a fundamental change that freed from the original style that characterized the $16^{\text {th }}$ and $17^{\text {th }}$ centuries AD. The new style managed to depict the arch in a conical shape turning upwards with a serrated line that occupies most of the mihrab field, which appears devoid of decoration. The arabesque ornaments adorn the two spandrels of arch, but in less precision in drawing ${ }^{(\mathrm{x})}$.

\subsubsection{The city of Giordes:}

It is located in to the west of Anatolia, about sixty miles to the east of Izmir ${ }^{(\mathrm{xi})}$. The Giordis prayer rugs come first in the Ottoman prayer rugs. The experts agreed that Giordis was highly distinct of its unparalleled production of magnificent prayer rugs ${ }^{\text {(xii) }}$. 


\section{The Most Important Features of Giordis Prayer Rugs:}

- They are generally small in size.

- Giordis rugs were distinguished from Turkish carpets in general by their short pile, as well as their tight texture.

- The mihrab in Giordis rugs is smaller than that of other types of prayer rugs and is based on two or more columns. As for the depictions, they are minute, with pale colors and tight weaving. The frame is narrow and there are several thin strips between it and the pile (body) of the rug ${ }^{\text {(xiii) }}$.

\subsubsection{The city of Kula:}

It is located in the center of western Anatolia, between the cities of Izmir and Ushaq. There is a great similarity between Kula and Giordis rugs due to the close distance between both cities ${ }^{\text {(xiv) }}$. Hence, the distinction between both types is of great precision, especially in early rugs dating back to the beginning of the $12^{\text {th }}$ century $\mathrm{AH} / 18^{\text {th }}$ century $\mathrm{AD}^{(\mathrm{xv})}$.

\section{The Most Important Features of Kula Prayer Rugs:}

- Kula prayer rugs were distinguished by their fine fabric of wool, tight knots, short piles and soft delicate touch ${ }^{(\mathrm{xvi})}$.

- The mihrabs are simple and their arches varied in shape that sometimes take the form of a triangle with an obtuse angle. Most of the time it consists of graduated lines, although in some examples they are distinguished by their height and the presence of two prominent pillars inside the mihrab, which may be lobed in shape.

- The colors of Kula rugs are bright, with a clear tendency to use yellow, blue, and red ${ }^{\text {(xvii) }}$.

\subsubsection{The city of Ladiq:}

Ladiq is located in the northwest of Konya in central Turkey. This region was marked with producing many dated prayer rugs that are preserved in museums, which testify that the second half of the $12^{\text {th }}$ century $\mathrm{AH} / 18^{\text {th }}$ century $\mathrm{AD}$ represents the peak of the prosperity and production of this type of rugs ${ }^{\text {(xviii) }}$.

\section{The Most Important Features of Ladiq Prayer Rugs:}

- Ladiq prayer rugs can be distinguished easily by the presence of a wide band at the top or bottom of the mihrab that contains shapes resembling adjacent arches similar to arrows hanging from the branches of the lily and tulip, that played a major role in their decoration. They formed an essential element in decorating the main central strip of the frame and it was painted 
in various styles, such as a right angle alternating with a geometric rosette. The later styles evolve this shape into a wavy plant branch that holds the stylized lily alternating with a geometric rosette ${ }^{(\mathrm{xix})}$.

- The late production of Ladiq prayer rugs is distinguished by its graded arch in the form of muqarnas, and the fields of mihrabs are often devoid of decoration ${ }^{(\mathrm{xx})}$.

\subsubsection{The city of Milas:}

The city of Milas is located in the southwest of Anatolia on the coast of the Aegean Sea. It is one of the important centers that gained wide fame in the production of distinct rugs with unique features that facilitate their identification. They form an important milestone in the art of rug-making in Turkey since the $18^{\text {th }}$ century AD/ $12^{\text {th }}$ century $\mathrm{AH}^{(\mathrm{xxi})}$.

Milas prayer rugs are of significant position because they are of rare value that added them to the world-known collections of rugs. They are dated back to the $12^{\text {th }}-13^{\text {th }}$ centuries $\mathrm{AH} / 18^{\text {th }}-19^{\text {th }}$ centuries $\mathrm{AD}^{(\mathrm{xxii})}$.

\section{The Most Important Features of Milas Prayer Rugs:}

- Milas prayer rugs are marked with the unique design of their arches of mihrab, which has a rhombus shape and the small size of its mihrab, which occupied less than one-third of the rug, while the frame occupies the largest part.

- Fine wool was used in making Milas rugs, which were mostly loosely woven, and the number of their knots ranged between 48-96 per square inch.

- Milas rugs were distinguished by their decorative units of rhombus on the inside with eight flowers with their small buds extending outwards, as each unit appeared as a sparkling diamond decorating the mihrab field.

- Milas rugs are adorned with cheerful colors, such as the reddish apricot of the pile and the yellowish green in coloring the decorative elements of the frame.

\subsubsection{The city of Bergama:}

This type of prayer rugs is attributed to the city of Bergama, one of the ancient cities of Western Anatolia. This city is considered an ancient center of carpet-making as it used to produce carpets dating back to the $16^{\text {th }}$ century AD / $10^{\text {th }}$ century $\mathrm{AH}^{\text {(xxiii) }}$.

\section{The Most Important Features of Bergama Prayer Rugs:}


- Fine wool was used in making Bergama rugs, which marked with their lengthy piles, and the number of their knots ranged between 54-60 per square inch.

- The mihrabs of the Bergama rugs were distinguished by their simplicity, and the arch of mihrab is depicted in the form of a triangular apex with an obtuse angle.

\subsubsection{The city of Kirsehir:}

This city is located in the center of Anatolia, and the Kirsehir prayer rugs were woven in a city of the same name in Central Anatolia. Its rugs are very similar to those of Mudjur that are located in the same district of Kirsehir, whether in their general characteristics or in the decoration of frame ${ }^{(\mathrm{xxiv})}$.

\section{The Most Important Features of Kirsehir Prayer Rugs:}

- The Kirsehir prayer rugs are distinguished by their graded arches of mihrab that took several lines ranging from three to six of different colors. These lines extended to surround all sides of the mihrab in a position separate from the frame line, which made the mihrab appear to be hanging ${ }^{(\mathrm{xxv})}$.

- The field of mihrab in Kirsehir prayer rugs may be devoid of decoration or occupied with various plant elements in a geometric style dominated by carnations, lilies, or geometric units.

- The colors used in Kirsehir prayer rugs were dark and pale, showing the primacy of red and green ${ }^{(\mathrm{xxvi})}$.

\subsubsection{The city of Mudjur:}

The city of Mudjur follows the district of Kirsehir and is considered an important center of Turkish carpet weaving. Most of the production of this city was of prayer rugs, which were very similar to those of Kirsehir, but the difference is that the colors in Mudjur prayer rugs were brighter and more splendid ${ }^{\text {(xxvii) }}$.

\section{Features of Mudjur Prayer Rugs:}

- Mudjur prayer rugs are woven from fine wool that is distinguished by its length, luster of pile. The number of knots ranges between 70: 63 knots per square inch.

- They are distinguished by the shape of mihrab, which is very similar to that of Kirsehir prayer rugs, that is made up of several graded lines. The keystone of its arch took the form of an arrowhead $^{\text {(xxviii). }}$.

- The decorations of Mudgur prayer rugs in general tends to be geometric. They are characterized by using the Kirshahr colors but in brighter and stronger manner ${ }^{(x x i x)}$. For example, the red 
color was used in two or three shades, especially in the field of $\operatorname{mihrab}^{(\mathrm{xxx})}$.

\subsubsection{The city of Mekry:}

The city of Mekry is located near Milas, on the coast of Asia Minor, facing the island of Rhodes. Mekry produced prayer rugs in the late nineteenth and early twentieth centuries. The museums and private collections of Cairo include a limited number of such rugs.

\section{Features of Mekry Prayer Rugs:}

- This type is made of wool and its fabric is loose, and its knots ranges between 42 and 58 per square inch.

- The field of mihrab occupies a small area, and its arch consists of an obtuse-angled triangle head that is crowned with a crenellation.

- Mekry prayer rugs were distinguished by the use of red in the pile of mihrab, white on the two spandrels of arch, and yellow was widely used, in addition to light and dark blue as well as the green and purple to a lesser extent.

\subsubsection{The city of Konya:}

The city of Konya is located in central Anatolia, and it is the capital of the region named after it ${ }^{\text {(xxxi) }}$. The name Konya has been associated with the history of early Anatolian carpets (Seljuk carpets), which is the first center of the Turkish carpet industry ${ }^{\text {(xxii) }}$. Konya is considered one of the most prominent centers in the Islamic world in carpet weaving. The traveler Marco Polo stated that the Konyan carpets in the Seljuk era were the most beautiful in the world of the time (xxxiii) $^{\text {. }}$

\section{Features of Konya Prayer Rugs:}

- Coarse and thick wool was used in making this type of rugs, which resulted in a thick and loose fabric with a long pile. The number of knots in this type of rugs ranges between 44: 56 per square inch.

- Konya prayer rugs were distinguished by the diversity of their mihrabs. For example, it can be found that the arch occupies the top of the mihrab field in the form of a small rhombus that curved ornaments extend from its sides in sparkling diamond shape, reminiscent of the decorative features of Milas rugs.

- Konya rugs are distinguished by their cheerful and bright colors of crimson red, light red, white, purple, light blue and black. 


\subsection{Description:}

The international museums and private collections preserve large numbers of Turkish prayer rugs dating back to the Ottoman era, many of which need to be studied. Hence, this research will deal with seven out of nine rugs that will be published for the first time.

\subsubsection{Rug 1}

\section{Prayer rug, Ushak Style. Plate (1)}

- Date: the late nineteenth century AD / thirteenth century AH.

- Dimension: 144 x $102 \mathrm{~cm}$.

- Warp: Two strands of raw wool.

- Weft: Two strands twisted into two rows of raw wool.

- Knot: Gördes, 30 knots per square inch.

- Colors: Light and dark brown, white, dark green, light yellow, and pink.

- Dye: Natural dyes.

- Conservation Condition: Good.

- Source: Private Collection.

- Publication: It is published here for the first time.

- Description:

- Field of Mihrab:

The rug is mediated with a decorative prominent arch, from which a bouquet of flowers representing a mosque-lamp (mishkah) consisting of blooming branches of flowering carnations. Each side is attached to a flying buttress, and they are all rested on two columns. The internal section of each column is decorated with a collection of hexagonal flowers, and both sides of each column are adorned with two rows of carnations. The base of the mihrab is ornately decorated with five bunches of carnations, the middle of which is the biggest.

- The two Spandrels of the Arch:

They are identical in decoration, adorned with carnations, and they are surmounted by a panel decorated with stylized geometric motifs and floral branches.

- Rug Frame:

The rug frame is divided into three bands by thin stripes: 
- The Middle Band: It is divided into three sub-bands by thin stripes. The middle band is decorated with geometric motifs, each of which is mediated with a rosette surrounded by floral branches. As for the shapes of rectangles separating between the geometric motifs, they are decorated with small triangular shapes including small, repeated and adjacent rosettes.

- The inner and outer band : of the rug are similar, so they are adorned with floral motifs consisting of stylized small rosettes.

\subsubsection{Rug 2}

Giordes Shobokli Sinekli Style Prayer Rug. Plate (2)

- Date: The early nineteenth century $\mathrm{AD} /$ thirteenth century $\mathrm{AH}$.

- Dimension: 189 x $131 \mathrm{~cm}$.

- Warp: Two strands of raw wool.

- Weft: Single strand in two rows of dyed wool.

- Knot: Giordes - 90 knots per square inch.

- Colors: White, Red-violet, olive green, reddish brown, yellow, and dark blue.

- Dyes: Natural dyes.

- Conservation Condition: Good.

- Source: Private Collection.

- Publication:

- Published here for the first time.

- Description:

- Field of Mihrab:

The floor of the mihrab is decorated with dark blue and has white flowers. The center of the mihrab field is an arch in the form of an isosceles triangle. The lines of the arch extend around the mihrab field and outline it with lines decorated with carnation flowers surrounding the arch of the mihrab and all its sides.

- Spandrels of the Arch:

- The two spandrels of the arch of rug are filled with individually repeated carnations in the form of flowers that look like little butterflies. They are repeated regularly and painted in red-brown or yellow.

- The mihrab field is outlined from the top and bottom by two different decorative panels. The upper includes bunches of carnations with wide leaves and sharp 
serrated ends. As for the bottom panel, it includes stylized painted carnations.

\section{- Rug Frame:}

The rug frame is divided into three bands, of which the middle is the largest.

- The Middle Band: It is divided into seven then sub-bands. It is decorated with small flower buds repeated in regular rows.

- The Inner Band: It includes three bands decorated with small units of carnations drawn in a narrow band and are repeated regularly.

- The Outer Band: It includes three narrow bands. Each is decorated with a horizontal row of carnation buds and flowers that are repeated regularly.

\subsubsection{Rug 3}

\section{Prayer rug in the style of Kula. Plate (3)}

- Date: The nineteenth century AD / the thirteenth century AH.

- Conservation Place: The Museum of Islamic Art, Cairo.

- Record No.: 24488

- Dimension: 138 x $203 \mathrm{~cm}$.

- Warp: Yarns of unpainted wool.

- Weft: two strands in one row of dyed wool.

- Knot: Giordes, 81 knots per square inch.

- Colors: White, dark olive green, blue, and beige.

- Dye: Natural dyes.

- Conservation Condition: Good.

- Source: Bought.

- Publication:

- Published for the first time.

- Description:

- Field of Mihrab:

The field of mihrab is adorned with an equilateral lobed arch with two prominent fringes. There is a decorative column on each side and both are painted as if they are hanging from the arch instead of being two pillars for it. Their interiors are decorated with repeated roses and their sides are surrounded by extending carnations. There is a large cypress tree hanging from the arch of mihrab.

- The two Spandrels of the Arch: 
They are decorated with flowering branches painted in a flexible, close-to-nature Arabesque pattern. They include carnations, lilies and stylized leaves. At the top of the mihrab field, there is a rectangular panel that includes floral units of stylized roses. There is a thin band of small flowers surrounding the field of mihrab.

○ Rug Frame:

It is divided into three bands by thin bands, and their decorations are as follows:

- The Middle Band: It is the largest and is decorated with an ornamental unit consisting of palmette fans drawn in a stylized shape similar to the body of a scarab that each side ends with a wing, each of which ends with a stylized fruit resembling the apple. Each unit is separated by a decorative flower that also has two wings.

- The Inner Band: It includes floral branches drawn in a wavy manner, forming equal areas with flowers and flower buds.

- The Outer Band: It is similar to the inner band.

\subsubsection{Rug 4}

Prayer Rug, Ladik Styke, Plate (4).

- Date: The eighteenth century AD / twelfth century AH.

- Dimensions: 121 x $216 \mathrm{~cm}$.

- Warp: Two strands of raw wool.

- Weft: Single strand in two rows of dyed wool.

- Knot: Gordies, 70 knots per square inch.

- Colors: Dark blue, bright red, dark red, dark brown and offwhite.

- Dye: natural dyes.

- Conservation Condition: Good.

- Source: Private Collection.

- Publication:

- Published for the first time.

- Description:

- Mihrab Field:

The field of mihrab is adorned with an arch in the form of a triangular vertex, drawn from several stepped lines of which a curved ornament comes out. The capstone is crowned with the form of a crenellation. As for the field of mihrab, it is devoid of decoration, but its sides are 
surrounded by small individual flowers that are repeated in inclined units.

- The Two Spandrels of the Arch:

It includes geometric quadrilateral quadrilateral flowers and a jug motif. The right side of the spandrel is decorated with a geometric unit of serrated lines in the form of an inverted triangle. Both spandrels are topped by wide panel adorned with the shapes of adjacent crenellations, from which and from top of them six lilacs come out. Each of these has a long stem with buds of the lilacs. All patterns are drawn in a stylized and symmetrical repetition.

- Rug Frame:

It is divided into four bands by means of thin bands decorated with dotted motifs.

o The First Band: is adorned with a zigzag floral branch that takes the form of right angles that confine between its sides small, quadrilateral geometric flowers.

o The Second Band: includes a wavy plant branch that takes the shape of the letter S, from which flower buds come out.

o The Third Band: It includes two units. The first consists of a flower of a stylized lilac with a stem that its both sides has two three-leaf carnations. They are adjacent to two floral leaves. The other unit consists of an eight-sided stylized rosette surrounded by four tripartite carnations. These two units are exchanged in an alternating repetition.

o The Fourth Band: It is similar to the second band.

\subsubsection{Rug 5}

Milas Prayer Rug. Plate (5)

- Date: The eighteenth century AD / twelfth century AH.

- Dimensions: 115 x $152 \mathrm{~cm}$.

- Warp: Two strands of raw wool.

- Weft: Single strand in two rows of dyed wool.

- Knot: Giordes 64 knots per square inch.

- Colors: light and dark red, ivory white, yellow, dark brown, and light blue.

- Dyes: natural dyes.

- Conservation Condition: Good. 
- Source: Private Collection.

- Publication:

Published for the first time.

- Description:

- Mihrab Field:

O It is adorned with a lozenge-shaped arch extending from the sides of the mihrab and its arch consists of flower buds painted individually and diagonally. In the middle of the mihrab field, there is a blooming collection of flowers consisting of a plant stem with branches bearing stylized lilacs, other quadrilateral and flower buds. There is also a quadrilateral flower in the middle of the arch of mihrab.

○ The Two Spandrels of the Arch:

- They include four palmetto stylized fans arranged symmetrically, with straight and intersecting lines interspersed with a geometric octagonal flower. There is a flower on each side.

○ Rug Frame:

It is divided into three thin bands with dotted coration.

- The Middle Band: It includes lozenge shapes decorated with minute motifs, surrounded by lily flowers that alternate with stylized palmette fans and octagonal roses.

- The Inner Band: It has three lines of dotted ornaments that divide the band into two equal sections. The first is decorated with dotted ornaments exchanged in a geometric shape, and the second includes geometric shapes through a line (zigzag).

- The Outer Band: It has quadrilateral geometric flowers in an octagonal frame. They are repeated and adjacent.

\subsubsection{Rug 6}

\section{Mudjur Style Prayer Rug (plate 6).}

- Date: The eighteenth century AD / twelfth century AH.

- Dimensions: 118 x $161 \mathrm{~cm}$.

- Warp: Two strands of raw wool.

- Weft: Single strand in two rows of dyed wool.

- Knot: Giordes 57 knots per square inch. 
- Colors: Dark red, light green, light and dark blue, yellow, ivory white, and violet.

- Dye: Natural dyes.

- Conservation Condition: Good.

- Source: Private Collection.

- Publication:

Published for the first time.

- Description:

○ Mihrab Field:

- It is devoid of ornamentation. One can see the arch of mihrab, drawn from several graded lines. The keystone of the arch takes the form of a crenellation. The mihrab is surrounded by single three-leaf carnations, each with a stem, which is repeated diagonally.

- The square of the mihrab is outlined by a rectangular panel that includes intertwining geometric motifs consisting of the shapes of crenellations that are adorned with curved decorations. There is a ornament in the form of a hook in the spaces between such crenellations.

- The Two Spandrels of the Arch:

They include two opposite jugs and geometric units. Both spandrels of the arch are surrounded by a zigzag band with dotted decorations.

- Rug Frame:

It is divided into three bands by means of thin sections with a zigzag line and dotted decorations.

- The Inner Band: It is divided into repeated lozenges, each of which includes a quadrilateral geometric flower. As for the spaces between the lozenge shapes, they are separated with geometric elements from the (camel pad) decoration. These are repeated in a way that appears as tiles.

- The Middle Band: It is decorated with geometric units representing octagonal rosettes, drawn interchangeably and in harmony.

- The Outer Band: It is adorned with geometric units, each of which looks like a scarab. 


\subsubsection{Rug 7}

Mudjur Shobokli Style Prayer Rug. Plate (7)

- Date: The first half of the nineteenth century AD / thirteenth century AH.

- Conservation Place: The Museum of Islamic Art, Cairo.

- Record No.: 83

- Dimensions: 108 x $157 \mathrm{~cm}$.

- Warp: Two strands of raw wool.

- Weft: Single strand in two rows of dyed wool.

- Knot: Giordes 62 knots per square inch.

- Colors: Bright red, dark red, light blue, black, dark, light purple, yellow, brown, ivory white.

- Dyes: Natural dyes.

- Conservation Condition: Good and thoroughly restored.

- Source: Collection of Prince Muhammad Ali.

- Publication:

- Published for the first time.

- Description:

- Mihrab Field:

The field of mihrab is adorned with an arch of several graded lines that go upwards forming the shape of a crenellation. A small chandelier hangs down from the arch and the lines of the arch extends to surround the mihrab, which is separated from the outlining line. The arch is surrounded by single units of quadrilateral geometric flowers, and the floor of the mihrab has rows of stylized geometric roses with white leaflets. The mihrab is surrounded with a thin dotted band.

- The Two Spandrels of the Arch:

They are the same, and each is distinguished by the shape of a jug topped by two octagonal geometric flowers.

- Rug Frame:

It is divided into three bands, of which the middle is the largest.

- Middle Band: It is divided into five thin bands, adorned with small buds repeated in regular rows.

- Inner Band: The main element of its decoration is a wavy floral branch that surrounds between its parts flower buds that are repeated regularly.

○ Outer Band: It includes a wavy floral branch. 


\subsubsection{Rug 8}

Mekry Style Prayer Rug. Plate (8)

- Date: The late nineteenth century AD / thirteenth century AH.

- Dimensions: 122 x $157 \mathrm{~cm}$.

- Warp: One strand of raw wool.

- Weft: Single strand in two rows of dyed wool.

- Knot: Giordes 58 knots per square inch.

- Colors: red, yellow, orange, light blue, dark purple, ivory white and black.

- Dyes: Natural dyes.

- Conservation Condition: Good.

- Publication:

- Published for the first time.

- Description:

- Mihrab Field:

It shows the arch of mihrab drawn from stepped lines, extending around the field of mihrab, from which bunches of flowers extends in individual repetition. In the middle of the mihrab field, there are distinctively drawn flowering branches. A crenellation form extends from the top of the arch, and there is a wavy floral branch adorning the sides of mihrab.

- The Two Spandrels of the Arch:

The two spandrels of the rug knots are adorned with individually repeated carnations that look like little butterflies repeated regularly. They are painted in redbrown or light blue. The field of mihrab is outlined by a decorative panel that includes octagonal bunches of flowers arranged in a geometric stylized shape.

\section{- Rug Frame:}

It is divided into seven bands by thin lines.

- First Band: It is decorated with geometric units in the form of an (S).

- Second Band: It is adorned with small S-shaped geometric motifs in repeated individually.

- Third Band: It includes carnations painted individually in duplicate units adjacent to each other.

- Fourth Band: It includes a row of flowers painted individually and alternately.

- Fifth Band: It is similar to the third band. 
- Sixth Band: It includes a wavy floral branch interrupted by stylized flowers with vertical bands, while the horizontal ones are decorated with stylized octagonal flowers.

\subsubsection{Rug 9}

Konya style Prayer Rug. Plate (9)

- Date: The nineteenth century AD / the thirteenth century AH.

- Dimensions: 110 x $118 \mathrm{~cm}$.

- Warp: Two strands of raw wool.

- Weft: One strand in five rows of dyed wool.

- Knot: Giordes 56 knots per square inch.

- Colors: Predominated with scarlet red, light red, light orange, light blue, purple, black and white.

- Dyes: Natural dyes.

- Conservation Condition: Good and thoroughly restored.

- Publication:

Published for the first time.

- Description:

- Mihrab Field:

The shape of mihrab appears in the form of a large crenellation that narrows at its end and extends to define both sides of the mihrab independently from its defining outline. They meet at the bottom to form an entrance that achieves balance in the design. The mihrab is drawn from a band of geometric motifs of a zigzag line that confines between its angles some alternating triangles. The field of mihrab is adorned also with stylized geometric elements in the form of composite quadrilateral and octagonal rosettes as well as stylized carnations and their buds. In addition, it is adorned with various geometric shapes, including curved ornaments. Both sides of the mihrab are surrounded by two rows of triangular shapes in a continuous repetition. As for the horizontal side, it is decorated with small quadrilateral geometric rosettes.

- Rug Frame:

It is divided into three band by means of thin strips:

o The Middle Band: is adorned with geometric units of intersecting lines in two different designs.

- The Inner Band: It has a zigzag line that forms small triangles in alternating positions.

○ The Outer Band: has a zigzag line. 


\section{Analysis:}

\subsection{First: Decorative Elements:}

\subsubsection{Decorations Inspired from Architectural Elements:}

\section{The Mihrab:}

The mihrab in the prayer rugs symbolizes that of the mosque. It marks the direction of Qibla (prayer destination) to which all Muslims must turn their faces during prayer, i.e., towards the Grand Mosque in Makkah Al-Mukarramah ${ }^{\text {(xxiv) }}$.

The Turkish prayer rugs are distinguished by the specific shape of mihrab in its center. This design can be seen clearly in individual prayer rugs. As for the large rugs that can be used by more than a performer of prayers, they were distinguished by the presence of two or more adjacent mihrabs in one row to perform the congregational prayer.

\section{Arches:}

The arches of the mihrabs usually occupy the middle of the rug, and the shape of arches varies from a region to another. For example, in the rugs of Kula, the arches sometimes extend downwards until reaching the frame of the rug with obtuse angles (Plate 3). As for the arch of mihrab in Ladik rugs, it includes the shape of a crenellation crowning it from the top (Plate 4).

As for the Giordes rugs, they are distinctively drawn in the form of an equilateral triangle with an elongation that ends with an acute angle that turns to be an obtuse near the top of the arch. So, the keystone to the arches has an obtuse angle design.(Plate 2)

As for the rugs of Milas, they are particularly distinguished as the arch of mihrab is drawn in the form of stars or rhombuses (Plate 5 ). The arch of mihrab appears in Mudjur rugs in the form of the vertex of an equilateral triangle (Plates 6, 7).

The arch of mihrab is drawn from several straight lines on the older prayer rugs or is drawn with stepped lines, perhaps the craftsman intended to simulate the shape of the muqarnas that adorns the hood of mihrab in the mosque.

The lines of arches of mihrabs in the early prayer rugs extended without decoration to outline the field of mihrab. Later, they were adorned with carnations and sometimes the lilacs.

\section{Columns:}


The Turkish artist used columns as an architectural element in decorating some prayer rugs in a way resembling the shapes of the columns adjacent to the arches of mihrabs in mosques.

In some rugs, the niche of mihrab is based on two or more columns, of which some are simple and end at the bottom with a base on which it rests. As for its top, it is crowned with the mihrab arch, which indicates that the rug dates back to an early era.

There are some rugs that combine the shape of columns, and the flowering lines that outline the sides of mihrab. Perhaps this is due to the traditions of the Turks who used to place two large candlesticks, each of which had a huge candle in some mosques.

\subsubsection{Floral Ornamentations}

Floral ornamentations are one of the most important types of decoration that the Turkish weavers have used to decorate prayer rugs. This decoration was at first simple, then its forms became more complicated later, as it was drawn in a stylized or abstract manner or in a way depicting reality, where one can see plants, trees and flowers represented in a style depicting nature in terms of shape and color. They have been arranged and distributed in decorative positions that indicate the Ottoman artist's ability and skill of diversification and innovation. The Floral ornamentations carried out on Turkish prayer rugs can be divided into two main types as follows:

\section{Stylized Floral Ornamentations}

The Ottoman artist used unrealistic ornamentations that detached from reality or nature, and this was known as the stylized method. It can be found clearly that all Turkish prayer rugs were decorated with stylized floral ornamentations and those far from nature. Examples of these can be seen in the artifacts under investigation in the shapes of palmette fans (Plates 3, 5).

\section{Floral Ornamentations Close to Reality}

The Ottomans were inspired by their local environment and there are many elements of unmatched realistic floral ornamentations can be seen in their artifacts. For example, they used the flowers significantly in that era, such as carnations, lilacs, varieties of lilies and roses, as flower gardens spread everywhere. Such gardens could be found in places such as public parks, around mosques and cemeteries, inside homes and palaces.

The artists found in the plants and flowers of their country a rich source to depict when implementing their decorative elements. Some 
examples of these floral ornamentations appeared in the rugs under investigation as follows:

Carnation flower: It is a flower that has roots in popular legacies and was highly popular to the Turks. They considered it an unrivaled symbol of happiness, wisdom, and knowledge. They were concerned with cultivating multiple types of it and all applied arts in the Ottoman era had a large share of it ${ }^{(\mathrm{xxxv})}$. They were depicted largely on the prayer rugs, so one hardly finds a prayer rug devoid of such depictions of carnations. It was used widely in the rugs under investigation, so it appeared in Pl. (1, 2, 3, 4, 6, 8, 9), and in Pl. (1), A carnation appeared to form the pillars of mihrab, and also served as a base for these columns.

The carnation was used aesthetically, and the artist depicted it with wide leaves and serrated sharp tips, as if he wanted to imitate the shape of ceramic tiles. In addition, he ordered some of them next to each other regularly on the spandrels of arches as shown in Pl. (2).

The Turkish artist used pink carnations as chandeliers (mushkhah) on some prayer rugs as in Plate (1).

Lilacs (Tulib) flower: Turkish artists used this decorative element extensively, especially in the prayer rugs. This is evident in Plates (4, 5) where one can see them individually and with serrating edges.

Lilies: This decoration appeared in the two spandrels of an arch on a Kula rug, Plate (3). It can also be found in the decorations of the middle band of the rug depicted in Plate (5).

Roses: The Ottoman artist used them on a large scale as a basic element in decorating the prayer rugs. He used them to decorate the fields of mihrabs, the spandrels of arches and the frames of rugs. They took multiple forms, including stylized roses from nature as shown in Plates $(1,3,4,7,8)$, and geometric roses as in Plates $(5,6$, $7,9)$. The rose was drawn in a form combining its leaves around its calyx, and often its leaves are irregular due to the texture of the rug.

The quadrilateral and octagonal rosettes: They played a major role in decorating the bands outlining some prayer rugs, as in Plates $(4,6)$. They are used also in decorating the field of mihrab of some rugs as depicted in Plates $(5,9)$.

The floral Branches: During the century (13 AH / 19 AD) the Ottoman artist was interested in his artistic products, and the floral branches were executed on prayer rugs in a pattern showing contrast, symmetry, and overlapping. This decoration was characterized by stylization and inspiration from nature, as in Plates $(1,2,3,4,5,7,8)$. The Cypress Tree ${ }^{(\mathrm{xxxvi})}$ : Trees depictions on the Ottoman rugs in general were associated with specific designs. There were many types 
of these trees, the most important of which was the cypress, which received great attention from the Ottomans and became of unique significant elements and the most important features of Ottoman art. It can be seen in several artworks of the Turkish artist until it became one of the essentials of this art. This tree has been of special importance because they believed that it symbolizes eternity, because its leaves are ever-green throughout the season. Thus, it expresses the renewed and immortal life. It has been depicted in green to mimic its original color in nature. The cypress was represented in some Ottoman prayer rugs as shown in Plate (3).

\subsubsection{Geometric Patterns}

There were many forms of geometric patterns used in decorating the Turkish prayer rugs during the Ottoman era. These included the following:

The shapes of Triangles: The triangles were used in the decoration as independent elements of different dimensions to fill the empty space or space devoid of decoration, as they were executed within regular or opposite stripes ${ }^{\text {(xxxvii) }}$. It is hard to find a Turkish prayer rug without this decoration that outlines the field of mihrab, or decorates the bands that divide the frame. The Turkish artist used the zigzag line consisting of the shapes of triangles in alternating positions to outline the field of mihrab and the outer band. As for their interior sections, they were adorned with roses or small geometric units such as in the rug in Plate (3). Some rugs are adorned with the shapes of adjacent small triangles with vertices similar to arrows. Perhaps, this design is derived from the shapes of crenellations that crown the walls of mosques, especially since they were abundant on the panels outlining the fields of mihrabs. They may have aimed to simulate an architectural and decorative element associated with the mosque. This can be found in the rugs of Plates $(4,6)$.

Rhombus: The shapes of rhombus were used to divide the space of the two pillars on either side of the arch of mihrab in some prayer rugs, as in Plate (6). The Turkish artist was creative in drawing lozenges in the middle of geometric rosettes in some carpets, as they appeared in the inner band of the carpet frame, Plate (6).

The arches of Milas prayer rugs took the form of lozenges that characterized the prayer rugs in this region. This can be seen in the rug of Plate (5).

Rectangles: It is one of the common geometric shapes used by the Turkish artist in decorating the prayer rugs. The artist drew the 
shapes of rectangles, interspersed with roses and various geometric shapes as in the rugs of Plates $(1,3,6)$.

\subsubsection{Symbolic Motifs}

The Turkish artist, in his decoration of rugs, used forms that may have a symbolic meaning, i.e., he managed to transform the familiar natural form into a mental concept through the stylization of nature into abstracted shapes. Doing so, he was influenced by the Chinese artists who are attributed to the creation of symbols. This influence appeared clearly on Turkish prayer rugs, as a result of importing the Chinese textiles. Motifs in the decorative arts such as the palmette or arabesque are often highly stylized versions of the parts of plants. The Turkish artist has dealt with many of the decorative elements with stylization to create expressive motifs in which he mixed the decorative elements with other Islamic to match the spirit of Islamic $\operatorname{art}^{\text {(xxxviii). }}$.

\subsection{The Form of Chinese Clouds "Tai-tschi"}

It is a sponge-shaped decoration that Turkish artists borrowed from the Chinese and used in prayer rugs ${ }^{(\mathrm{xxxix})}$. For the Turks, the clouds have several meanings, whether before or after Islam. Reconsidering the ancient Turkish religions, it can be found that the clouds are one of the deities known to the Turks in Central Asia as they managed to worship the elements of nature like the earth, water, sky, rain and clouds. Meanwhile, depicting the clouds on prayer rugs is related to some Islamic meanings and some of the obligatory duties of prayer as it may symbolize the pure water with which a Muslim performs ablution before the prayer ${ }^{(\mathrm{xl})}$.

The Curved Shapes: They are various shapes that were implemented in multiple ways, but they are mainly related to the ornament that takes the shape of curved cross. This ornament was known to the peoples of the ancient world, especially the Greeks and Chinese. It meant for them the good luck, growth and fertility. Perhaps, it was symbolizing the solar deity. Its use was common in Turkish rugs, and perhaps the four sides of this curved shape denoted the four gods of the ancient Turks before Islam. It may be derived from the Turks belief that they governed the four regions of the earth. This form lost its significance by time and became a mere simple decoration ${ }^{\text {(xli) }}$. The curved shapes on the Ottoman prayer rugs varied as they included ornaments decorating the field of mihrab, as those on the rugs of Plates $(4,6,9)$.

1- The Chinese dragon, also known as "Long"(xlii): It is one of the Chinese forms that influenced the Turkish artist. This 
element drew attention in the decoration of Ottoman arts. The Turkish artist dealt with this shape in decorating the prayer rugs, especially Gördes and Kula rugs. He stylized it until it lost its familiar shape and took a twisted shape that its ends (head and tail) take the form of a floral leaf ${ }^{\text {(xliii) }}$.

\section{Second: Colors:}

In Ottoman art, some colors were associated with intellectual and ideological tendencies, some of which were of religious origins and some were popular and hereditary. The extensive use of bright colors in the Ottoman art is influenced by some mystical ideas denoting the light of $\mathrm{God}^{\text {(xliv) }}$.

The Turkish artist excelled using color mixtures and mixing colors with high consistency. He also excelled extracting colors from natural dyes such as animal and plant dyes.

The colors on the Turkish prayer rugs were suitable for their decorations that depicted floral motifs that were often colored in realistic colors as found in nature.

Here are some of the most important colors that distinguished the decorations of Ottoman prayer rugs:

\subsubsection{Red Color:}

Red has been the most prominent color of Ottoman art and the most used, especially in the period of originality and prosperity. The red color appears in various applied arts, including rugs.

For the Turks, the red color was associated with many connotations, as it symbolizes strength and victory, especially in the period of the booming of Ottoman art and the expansion of the state $\left(10^{\text {th }}-11^{\text {th }}\right.$ centuries $\mathrm{AH} / 16-17^{\text {th }}$ Centuries AD). It was also associated with some mystical meanings such as divine love and martyrdom for the sake of $\operatorname{God}^{(\mathrm{xlv})}$.

The association of this color with prayer rugs could be influenced by this idea of divine love. The red color in its light and dark shades has been common in the fields of prayer rugs as those in Plates $(2,3$, $4,6,7,8,9)$. It may be a reminder to the worshiper to martyr in the Path of God and strengthen his spirit to become closer to God in his prayers $^{(\mathrm{xlvi})}$.

\subsubsection{The White Color:}

This color is favorable to the soul because it brings comfort and reassurance to it. It was mentioned in the Noble Qur'an describing the faces of people of happiness and mercy. The Almighty said: " وَ ؤَمَّا

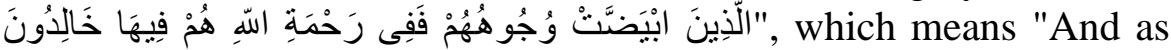


for those whose faces have been whitened, in the mercy of Allah they dwell forever"(xlvii).

For the Turks, it was associated with purity and serenity, as it symbolizes the Mohammedan light, which Sufism says is the light from which creatures were created. It is the spirit that extends to all prophets and messengers ${ }^{\text {(xlviii) }}$. The white color also symbolizes peace and tranquility when used on prayer rugs ${ }^{\text {(xlix) }}$.

The bright white and ivory white were sometimes used in drawing the field of mihrab, as in the rugs depicted in Plates $(1,2,4$, $5,6,7,8)$. It was also used in drawing multi-petal rosettes and different flowers as in the rugs depicted in Plates $(1,2,3,4,5,6)$.

\subsubsection{The Green Color:}

The green color has had its own significant presence in Islamic art that persisted throughout ages and times. It has been of particular importance for the Muslim artist, as it is one of the sacred colors that suggests the worshipper's obedience and journey towards the truth ${ }^{(1)}$.

In the Ottoman school of art, the green color was associated with paradise, whether God bestowed upon man in this world or promised to the believers in the Hereafter. It was a slogan for Ahl al-Bayt (People of the Prophet's House) in the Ottoman Sufism ${ }^{(\mathrm{li})}$.

Therefore, green was widely used in coloring objects associated with death and burial, such as the tomb domes and walls. This was associated with drawing green cypress trees in Ottoman shrines on prayer rugs known as "Mazarlik". It is possible that depicting the green cypress was intended to describe the everlasting greenness in the shrines in order to give the sense that heaven casts its permanent

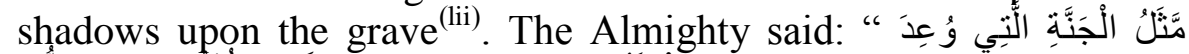

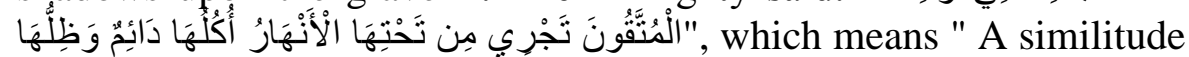
of the Garden which is promised unto those who keep their duty (to Allah): Underneath it rivers flow; its food is everlasting, and its shade"(liii).

The green color was widely used in Ottoman prayer rugs as it symbolizes the paradise promised to the worshipers. This can be seen clearly in the drawing of branches and floral leaves in many rugs as shown in Plates $(1,6,7,8)$.

\subsubsection{The Blue Color:}

The blue color in Ottoman prayer rugs is associated with some Sufi meanings as it may be a symbol of a Sufi order (Tariqa Rifa iyya) or it may be related to the idea of determination, so it was 
used in Ottoman prayer rugs to remind the worshiper to strive with diligence towards the rank of determination ${ }^{\text {(liv) }}$.

Blue was used in its various shades, such as light blue, sky blue, and dark blue in coloring the fields of mihrab and bands of frames as in the carpets in Plates $(2,4,6,7,8,9)$. It was used in coloring the floral leaves as in the rugs of Plates $(6,8,9)$.

\subsubsection{The Yellow Color:}

Yellow in Ottoman art is associated with brightness, light and sun $^{(1 \mathrm{v})}$. It was used in Ottoman prayer rugs in coloring the fields of mihrab and bands of frame as in the rugs of Plates $(1,2,3,6,7,8$, 9). In addition, it was used in drawing the floral branches and roses as in rugs of Plates $(1,2,3,4,5,6,7,8)$.

\subsubsection{The Black Color:}

The black was of little use in Ottoman art, perhaps because it is one of the most unfavorable to artists. So, it was of little use in Ottoman prayer rugs and can be seen only in the outer frames of rugs and outlining the floral leaves as in the rugs of Plates $(7,8,9)$.

\subsubsection{The Brown Color:}

Brown in its various shades, light and dark brown was common on Ottoman prayer rugs. It can be seen clearly in the bands of frame and in fields of mihrab as in Plates $(1,2,4,5,7)$.

\section{Conclusion:}

\subsection{Results:}

The Ottomans played a prominent role in Islamic art and immortalized in its record the pages of bright.

Scientific publication of nine Ottoman prayer rugs for the first time.

The design of prayer rugs, in general, was associated with the architectural and decorative elements of the mosque.

Milas rugs had a unique design that can be seen clearly in its arch of mihrab with the lozenge shape.

In most of the floral, geometric and animal ornamentations as well as mythological animal depictions, the scholars avoided finding special names or even referring to an interpretation of many of their decorative elements, as the Turkish artist made a radical change in the decorative motifs that stylized them completely from their nature. Hence, they lost many of their forms in order to fit the function and religious purpose of the prayer rug. 
Symbolism in the use of colors and ideological influences are evident in the colors of the prayer rugs.

The Ottoman artist depicted the floral motifs on Ottoman prayer rugs realistically and accurately, which indicates that he was very familiar with the names of flowers and how to differentiate between similar flowers in nature in terms of shape.

Carnations were used in decorating some Ottoman prayer rugs as a unique decorative element.

The interest in depicting carnation increased during the $12^{\text {th }}$ century $\mathrm{AH} / 18^{\text {th }} \mathrm{AD}$, which marked the golden age of this flower, as it was depicted in all Ottoman arts, the rugs in general, and the Giordes prayer rugs in particular.

The Ottoman artist succeeded in achieving the elements of balance and harmony in the general composition of prayer rugs, as the decorative elements were mixed in perfect harmony, in an indication to the artist's full awareness of such elements.

\subsection{Recommendations:}

Increasing awareness of the field of Islamic rugs. The study recommends preparing more shopping festivals and exhibitions on Islamic rugs, in order to emphasize the reuse of our artistic heritage, according to the distinct structural patterns that combine the Egyptian and Islamic character with the requirements of the age.

Compiling an artistic scientific encyclopedia on the aesthetics of Islamic arts. It should include pictures and explanations of the Ottoman rugs produced during the Islamic eras. In addition, this recommended scientific study should be carried out by an Arab Islamic body to preserve our cultural heritage and to facilitate the relevant future researches.

Using the plant and geometric motifs inspired from the Ottoman heritage in decorating carpet products to enrich the look and general taste of the audience.

Coordinating with the international tourism sector of the Tourism Promotion Authority, the Supreme Council of Antiquities, and the Islamic and Coptic Antiquities Sector to enlist the topic of Islamic carpets in the tourism exhibitions held in various countries of the world, especially those held in countries interested in Islamic heritage and culture such as Kazakhstan, Indonesia and Malaysia. 


\section{Plates}

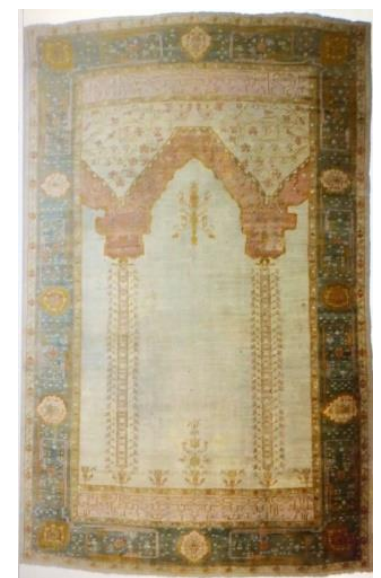

Plate (1)

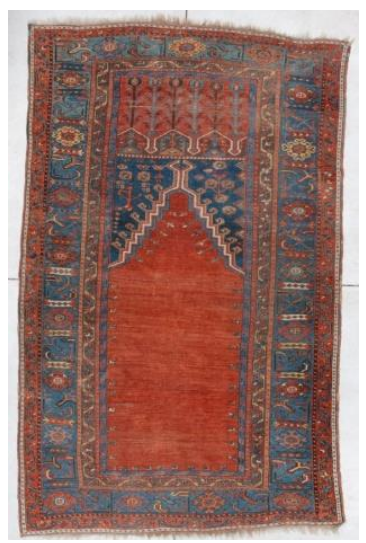

Plate (4)

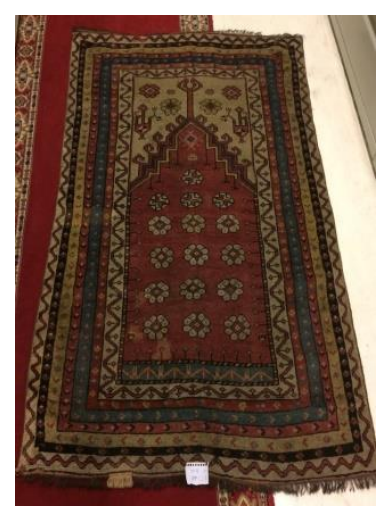

Plate (7)

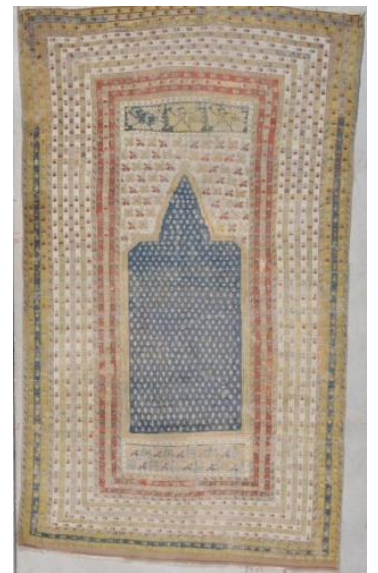

Plate (2)

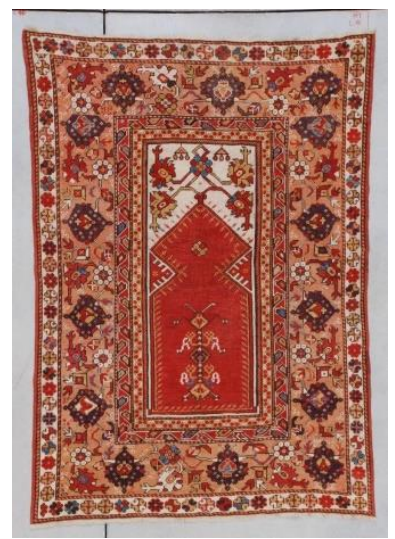

Plate (5)

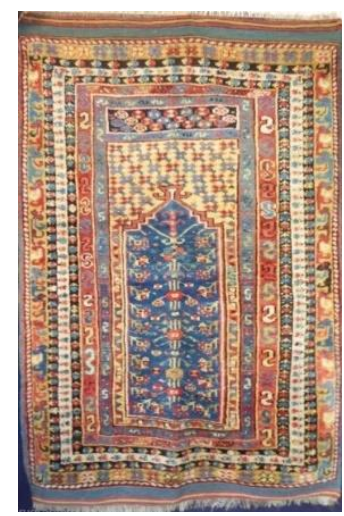

Plate (8)

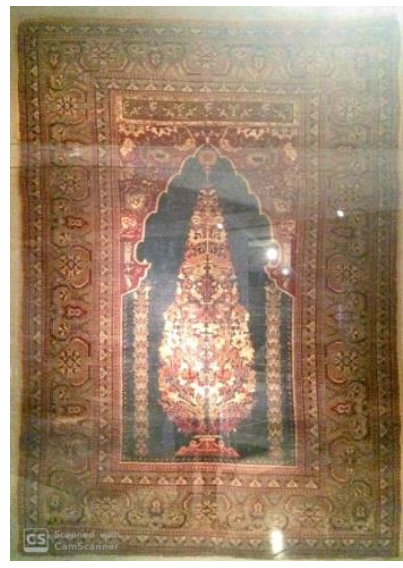

Plate (3)

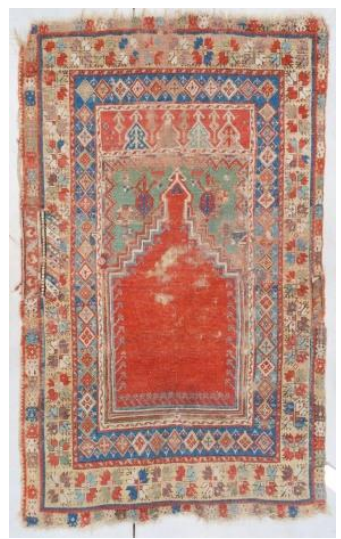

Plate (6)

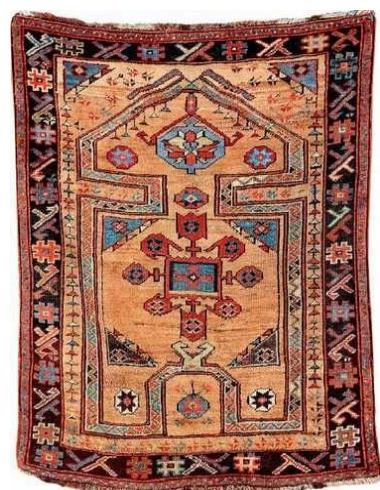

Plate (9) 


\section{References}

(i) Aslanapa, O., Turkish art and architecture, London, 1971, p. 291.

(ii) Historians and art experts have agreed that knotted rugs were discovered for the first time in places where the Turks existed in Central Asia. Despite some ancient civilizations knew some types of rugs such as the Assyrians, Babylonians and Achaemenids, the traditions of this art continued later among the Sassanids and Byzantines. However, these types of rugs were not of the knotted rugs, but they were made in a certain style of weaving and spinning, and sometimes they were decorated with some precious stones.

- Abdul Hafez, A, A., "Derasat fe al-Fan al-Turki". Al-Nahda alMasriya Bookshop, First Edition, Cairo, 2007 AD, P. 76.

(iii) Albasha, H., "Mawsoo'et al-Imara wal-Athaar wal-Fonoun alIslamiya", Vol. 2, 1st Edition, "Awraq Sharqiya, Beirut, 1999 AD, P. 130.

(iv) Abo AL-Fotouh, K., Derasat Lesagagid Giordes fe Do' Muthaf Qasr al-Manial, Supreme Council of Archaeology, P. 33.

(v) Stanely, F, R., Oriental Rugs and Rugs., George Feld\& Nicolson. Ltd., London, 1967, P.25.

(vi) Mostafa, M., Sajajid al-Salah al-Turkiya, Wizaret al-Ma'aref alOmomiya Printing House, Cairo, 1935 AD, P. 18.

(vii) Khalifa, H, R., "Al-Fonoun al-Islamiya fe al-'Asr al-Otmani". Zahra' al-Sharq Book Shop, Cairo, 2007 AD, P. 288.

(viii) Abdul Hafez, A, A., "Derasat fe al-Fan al-Turki", P. 84.

(ix) Khalifa, H, R., "Al-Fonoun al-Islamiya fe al-'Asr al-Otmani" , P. 305.

(x) Abo AL-Fotouh, K., "AlSijad alturky Alusmany", PHD. Thesis, Faculty of Archaeology, Cairo University, 1992AD, p67.

(xi) Derbeg, D., "'Amal al-Sajjad", Translated by Mahmoud al-Shal and Abdul Ghani al-Shal, Cairo, PP. 62-63.

(xii)Abo AL-Fotouh, K., "Derasat Le Sajajid Gördes fe Dou' Mut-haf Kasr al-Manial", Supreme Council of Antiquities, P. 26.

(xiii) Hassan, Z., "Funoon al-Islam", 1st Edition, Publications of the Library of the Egyptian renaissance, Cairo,1948, P. 427.

(xiv) Formenton, F., Oriental Rugs and Carpets, P.94.

(xv) Haak, H., Oriental Rugs, An illustrated Guide, Faber and Faber Limited, London, p.46.

(xvi) Abo AL-Fotouh, K., "AlSijad alturky Alusmany", p.85.

(xvii) Mostafa, M., Sajajid al-Salah al-Turkiya, p.13. 
(xviii) Al-Sherif, A, S., "Sajad al-Shark", Publications of the Ministry of Culture in the Arab Syrian Republic, Damascus, 1966, p. 34.

(xix)Abo AL-Fotouh, K., "AlSijad alturky Alusmany", p.95.

(xx) Aslanapa, O., "Funon altek we amaryhum", Translated by: Ahmed issa, Publications of the Centre of Researches of History, Arts and Cultures at Istanbul, Istanbul, 1987 AD, p.282.

(xxi) Albasha, H., "Mawsoo'et al-Imara wal-Athaar wal-Fonoun alIslamiya", Vol. 1, 1st Edition, "Awraq Sharqiya", Beirut, 1999 AD, P. 124.

(xxii) Abo AL-Fotouh, K., "AlSijad alturky Alusmany", p.100.

(xxiii) Aslanapa, O., "Funon altek we amaryhum", p.280.

(xxiv) Formenton, F., Oriental Rugs and Carpets, P.88.

(xxv) Abo AL-Fotouh, K., "AlSijad alturky Alusmany", p.101.

(xxvi) Hande Ayşegül ÖZDEMİR: ŞEYH ŞABAN-I VELİ VAKIF

ESERLERİ MÜZESINDE YER ALAN KIRŞEHİR SECCADE HALILARININ RENK, MOTIF VE KOMPOZISYYN ÖZELLIKLERININ INCELENMESİ, p.3092

(xxvii) Khalifa, H, R., "Al-Fonoun al-Islamiya fe al-'Asr al-Otmani, p.325.

(xxviii) Abo AL-Fotouh, K., "AlSijad alturky Alusmany", p.122.

(xxix) Abo AL-Fotouh, K., "AlSijad alturky Alusmany", p.124.

(xxx) Daniel Walker: Bulletin (St. Louis Art Museum), New Series, Vol. 18, No. 4, TURKISH RUGS (1988SUMMER), p.31.

(xxxi) Turk Ansiklopedisi; Cilte, XXII, Ankara, 1970, Konya, p. 193.

(xxxii) Abo AL-Fotouh, K., "AlSijad alturky Alusmany", p.131.

(xxxiii) Baziab, A, N., Konya Asmet Saltanit Salajikt Alrom", PHD. Thesis, Faculty of Islamic Law and Studies, Um Al-Qura University, Saudi Arabia, 1994 AD, p.378.

(xxxiv) Al-Basha, H., "Mawsoo'et al-Imara wal-Athaar wal-Fonoun al-Islamiya", V.2, P. 132.

(xxxv) Said, A, H.," "Alzakharef al-Nabatiya Ala al-Funoon alTatbikiya fe Asia al-Soghra", Unpublished M.A. Thesis, Faculty of Archaeology, Cairo University, 1433 AH / 2012AD, P. 285.

(xxxvi) Cypress: a slow-growing evergreen tree with good shape and strong stem, proverbial in its straightness. It is a perennial tree that grows abundantly in temperate climates, especially in southern Europe and western Asia. It is well known in the Sassanid art as the tree of life (Homa) for its evergreen leaves throughout the year. 
Abdul Salam, A, M., "Al-Funoon al-Islamiya fe al-Sin wa Athareha ala Funoon al-Yaban wa Korea (men Qarn 8: 13 H / Q 14: 19 Miladi)", Unpublished PhD. Thesis, Faculty of Arts, Helwan University, 1439 AH / 2018AD, p. 278.

(xxxvii) Ricard, p., Pour Comprendre L'art musulman en Afrique du nord et en Espagne et en Sicile, Hachette, Paris, 1924, p. 62.

(xxxviii) Abo AL-Fotouh, K., "Derasat Lesagagid Giordes", Supreme Council of Archaeology, P. 115.

(xxxix) Hassan, Z., "A-Sin wa Funoon al-Islam", Publications of the Centre of A-Raed Beirut, Lebanon,1941, P. 48.

(xl) Abdel-Dayem, M, N., "Al-Ta'therat al-'Aqaediya fe al-Fan alOtmani", Unpublished MA Thesis, Faculty of Archeology, Cairo University, 1989 AD, P. 79.

(xli) Abo AL-Fotouh, K., "Derasat Lesagagid Giordes", Supreme Council of Archaeology, P. 116.

(xlii) Dragon: A mythical animal that humans contrived many narratives and myths around. It is considered one of the most decorative forms associated with China and was known in Arab sources as a symbol of evil and appeared frightening. It was used in Islamic arts as a decorative element in various shapes indicating the Muslim artist's fertile imagination. It sometimes appears by wings of an eagle, claws of a lion, and the tail of a snake. Sometimes, it comes out in the form of clouds, so the dragon can be seen in most of its drawings flying among the clouds. Its extended body is covered with the peel, and in its head there are two horns and in its mouth sharp teeth. It is sometimes depicted in the form of a pair of dragons wrapped around each other in a wonderful formation with two interchangeable heads.

Muhammad, M, T., "Al-Ta'thirat al-Siniya Ala al-Aniya al-Zogagiya fe al-'Asr al-Mamluki", (Research submitted at the Sixth International Conference: Ancient Legacies between Transparency, Writing and Embodiment), Center for Papyrus Studies and Inscriptions, Ain Shams University, Cairo, 2015, pp. 36, 37.

(xliii) Arseven mentioned that this figure represents the five-toed dragon's foot, which he depicted as an amulet that protects evil. The artist may have intended with this decorative unit to depict the conflict between good and evil, and provided it with an amulet as if it symbolizes the victory of good over evil. 
Arseven, C., Les Arts decoratifs turcs, Constantinople l'an, 1902., p268.

(xliv) Mutawa, A, H., "Al-Alwan wa Delalat-ha fe al-Hadara alIslamiya ma Tatbiq Ala Namazig men al-Makhtotat al-'Arabiya", Journal of the General Union of Arab Archaeologists, Issue 18, 2016, p. 435.

(xlv) Mutawa, A, H., "Al-Alwan wa Delalat-ha fe al-Hadara alIslamiya", P. 435.

(xlvi) Abdel-Dayem, M, N., "Al-Ta'therat al-'Aqaediya fe al-Fan alOtmani", PP. 103-104.

(xlvii) Holy Quran: Surat Al Imran, Aya 105-106.

(xlviii) Abdel-Dayem, M, N., "Al-Ta'therat al-'Aqaediya fe al-Fan alOtmani", P. 117.

(xlix) ACKLES, Sharla Fell: Symbols and their meanings in the rugs and prayer rugs of the Turkish, Armenian and Persian traditions. Student Publications-Department of Art and Art History, 1998. p.10.

(1) Abdul Amir, L, S., "Al-Delala al-Rawhiya lelawn al-Akhdar fe al'Imara al-Islamiya", Babylon University Journal for the Humanities, Vol. 18, Issue 1, 2010, P.321.

(li) Mutawa, A, H., "Al-Alwan wa Delalat-ha fe al-Hadara alIslamiya", P. 435.

(lii) Abdel-Dayem, M, N., "Al-Ta'therat al-'Aqaediya fe al-Fan alOtmani", P. 109, 110.

(liii) Holy Quran: Surat Al-Raad, Aya 35.

(liv) Abdel-Dayem, M, N., "Al-Ta'therat al-'Aqaediya fe al-Fan alOtmani", P. 112..

(lv) Mutawa, A, H., "Al-Alwan wa Delalat-ha fe al-Hadara alIslamiya", P. 435. 